\title{
Workforce diversity management: a systematic literature review
}

\section{Yana Seliverstova}

University of Debrecen, Faculty of Economics and Business, Institute of Management and Organisation Sciences, Debrecen, Hungary

\begin{abstract}
The primary task of the paper is to propose a definition of the existing theoretical contributions to the term of workforce diversity management (WDM) in order to systematize present knowledge, clearly understand the definition of WDM in organizations and identify the gaps for future research. In this theoretical study, the Scopus database was used for sampling. 19 studies published since 2015 were identified, and then the selected papers were analysed according to key research definitions. Recently, the idea of diversity management (DM) acquires a new meaning; swiftly expanding its field and circulating around the world. WDM becomes a frequently significant part of Human Resource Management in corporations, as it helps companies to take a sustained competitive advantage in the current globalization and innovative age (Egerova, Jiřincová, Lančarič \& Savov, 2013; Manoharan \& Singal, 2017). The results of the research show that DM is perceived by a moderate number of existing publications as a method that helps to encompass both: a favourable corporate culture and organizational success. By assessing present studies on DM, the paper contributes to the literature on business and management and demonstrates the potential as the scrutinised field seems to be an attractive area for future research.
\end{abstract}

\section{Keywords}

inclusion, human resource management, labour market, organizations, content analysis.

\section{Introduction}

The increasing globalisation and the social changes in the world have lately led to the movement of free labour (Sanghvi, 2019), making the workforce diverse more than ever (Meena \& Vanka, 2017; Tamunomiebi \& John-Eke, 2020) and almost any organisation is free to form its diverse human capital. These factors have further magnified employees' interaction with each other (Ramsiary \& Raya, 2015) and generated new hurdles for firms in every business sector (Shen, Tang \& D'Netto, 2014), increasing the necessity for managing a diverse workforce.

Over the past decades, DM has received more attention from researchers. As evident, Figure 1 shows a rising amount of scholarly articles on the subject regarding the business and management field in the Scopus database over the period from 2000 to 2020 . A vital rise in publications can be noticed from 2010 due to the increasing variety of human capital and the reasons behind that fact were explained in previous studies as demographic changes of the labour market, the inclusion of migrants and ease of employee mobility (Özbilgin, Jonsen, Tatli, Vassilopoulou \& Surgevil, 2013; Urbancová, Hudáková \& Fajcíková, 2020). This proves the relevance of the research topic that is constantly emerging and will make a vast impact on the companies' structure in the future.

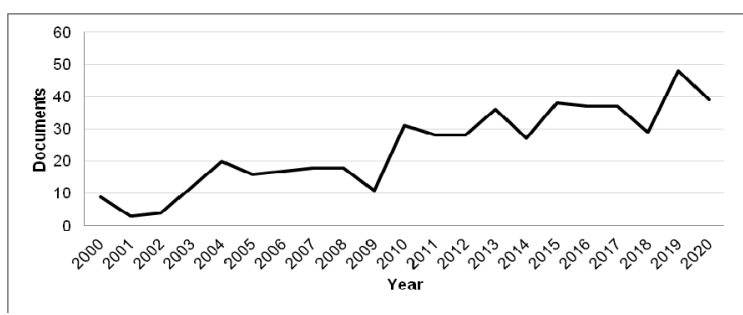

Figure 1 Number of publications on the diversity management topic per year Source: Scopus, 2020 
This theoretical study was conducted to understand how the notion of WDM is explained in business and management literature. Thus, the objectives of this paper are the (1) to analyse the definitions of WDM in the latest studies and (2) to identify current concerns and trend directions for future research on WDM. The systematic literature review was carried out using the Scopus database to examine the above-mentioned objectives. The conclusions are calling for future research and consideration of eliminating limitations in this field.

\section{The concepts of workforce diversity management}

A comprehensive definition of workforce diversity means heterogeneity and differences among employees in an organisation in terms of race, age, ethnicity, cultural background, physical abilities, religion, gender, sexual orientation, language, education, lifestyle, beliefs, appearance and economic status (Choi \& Rainey, 2010; Manoharan \& Singal, 2017; Pitts, 2009; Roosevelt Thomas, 1990; Inegbedion, Sunday, Asaleye, Lawal \& Adebanji, 2020; Saxena, 2014). The scholars frequently use different terms to refer to DM, such as "equality at the workplace", "diverse workforce", "equal opportunities", and "inclusion".

The concept of WDM emerged in the USA in the 1980s - 1990s and refers to Equal Employment Opportunity and Affirmative Action and was later basically formulated by Roosevelt R. Thomas Jr. (Mcdonald, 2010; Bridgstock, Lettice, Ozbilgin \& Tatli, 2010; Gröschl, 2011; Rabl, del Carmen Triana, Byun \& Bosch, 2020). Later, Fischer (2009) described DM as a management policy that designs to benefit from workforce diversity for the achievement of organisational goals.

In existing literature, a more frequently used definition of WDM belongs to Hubbard (2011), who defined it as "a process of planning for, organizing and supporting these collective mixtures in a way that adds a measurable difference to organisational performance". However, the analysed papers do not refer to that term; half of them explain DM from the same perspective, as management of individual employees' differences in order to contribute to organisational performance (Ashikali \& Groeneveld, 2015; Köllen, 2016; Lančarič, Chebeň \& Savov, 2015; Otaye-Ebede, 2018;
Ohunakin, Adeniji, Ogunnaike, Igbadume \& Akintayo, 2019).

Recently, managers and scholars have become more aware that diverseness of employees allows looking at many things and situations outside the box, from different angles and points of view, brings innovation and moves the company towards development and transformation. Therefore, in more recent research, the concept of DM gaining broad meaning, paying attention to the equal employment opportunities and staff well-being and explaining that all employees can pursue their goals without being hindered by gender, race, nationality or other qualities that are unrelated to performance (Ayega \& Muathe, 2018; Egerova, 2012).

\section{Research methodology}

The objective of the study is to examine and synthesize existing research, and, furthermore, deliver the evidence, thus, a systematic review approach will be applied for this study. The systematic review methodology is the most reliable and precise method to collect articles, which have severe conditions for search procedure and paper selection to be included in the research, and typically, carried to assess the nature of existing knowledge and gaps on specific issues on a distinct subject (Mengist, Soromessa \& Legese, 2020; Snyder, 2019).

To narrow down the study objectives, the keyword "Workforce diversity management" was applied in titles, abstracts and keywords of publications to investigate relevant literature indexed in the Scopus scientific database. Almost 1400 scientific articles have been found on Scopus. The Scopus database was chosen in view of its significance, interdisciplinary character and focus on high $\square$ quality research, published in peer $\square$ reviewed journals, acknowledged conferences and books. Data were retrieved on 30 September 2020. Table 1 presents the sampling process divided into five steps with a purpose to identify the studies for the current review.

Table 1 The articles collection method

\begin{tabular}{l|l|l}
\hline No & Step of the collection process & $\mathbf{N}$ \\
\hline 1 & $\begin{array}{l}\text { Studies identified in search (Scopus database) by } \\
\text { the keyword "Workforce diversity management" }\end{array}$ & 1390 \\
\hline 2 & $\begin{array}{l}\text { Studies identified by applying filters to exclude } \\
\text { irrelevant studies (English language, year, } \\
\text { subject area) }\end{array}$ & 228 \\
\hline 3 & $\begin{array}{l}\text { Studies identified after reading titles and } \\
\text { abstracts }\end{array}$ & 103 \\
\hline 4 & Studies identified by reading the full articles & 46 \\
\hline
\end{tabular}




\begin{tabular}{l|l|l}
\hline 5 & $\begin{array}{l}\text { Studies rejected after the analysis of abstracts } \\
\text { and full text of articles }\end{array}$ & 84 \\
\hline 6 & Study of the final research papers & 19 \\
\hline \multicolumn{2}{c}{ Source: The author }
\end{tabular}

To filter the large pool of papers, formation measures were implemented: 1) papers published in the English language; 2) articles published since 2015 ; 3) articles referring to "Economics, Econometrics and Finance" and "Business, Management and Accounting" subject areas, 4) excluding publications in Agriculture, Health science and Medicine (Scopus filters). After applied filters, 228 articles were identified and attentive abstract reading was performed. The further action was employed, eliminating from the research unsuitable or inaccessible studies for the users of the University of Debrecen. At this stage, 103 studies were identified for further consideration. Third, the abstracts of the papers were analysed with the purpose to exclude irrelevant studies, including articles related to the concept of diversity in top management teams, as it is not a direct focus of this and further research. In sum, a total of 46 studies related to the concept of WDM were read for this article, and as the fourth step, the review of the full texts was undertaken to identify and eliminate unrelated studies or studies provided little guidance to the research topic. In general, 84 studies were excluded by the author's primary search. As the fourth step, content analysis was applied with the purpose to find the key contributions and to classify existing concepts regarding the research objectives. Thus, at the fifth step, 19 publications were chosen as a final research sample. The complete reading of these articles allows identifying 47 authors attempting to define the DM concept. The findings of the literature review are published on the following pages. Furthermore, the articles cited in the retrieved studies have been evaluated and few of them are included in this research.

\section{Literature analysis}

In this chapter, further efforts toward identifying the meaning of WDM regarding the previously described methodology were made. Table 2 presents the results of the selected literature for the research analysis.

Table 2 systematic literature review sample on workforce diversity management

\begin{tabular}{|c|c|c|c|c|}
\hline No. & Year & Author(s) & Article Title & Journal Title \\
\hline 1 & 2015 & Ashikali \& Groeneveld & $\begin{array}{l}\text { Diversity management for all? An empirical analysis of } \\
\text { diversity management outcomes across groups }\end{array}$ & Personnel Review \\
\hline 2 & 2015 & $\begin{array}{l}\text { Lančarič, Chebeň \& } \\
\text { Savov }\end{array}$ & $\begin{array}{l}\text { Factors influencing the implementation of diversity } \\
\text { management in business organisations in a transition } \\
\text { economy. The case of Slovakia }\end{array}$ & $\begin{array}{l}\text { Economic Research- } \\
\text { Ekonomska Istrazivanja }\end{array}$ \\
\hline 3 & 2015 & $\begin{array}{l}\text { Urbancová, } \\
\text { Cermáková \& } \\
\text { Navrátilová }\end{array}$ & $\begin{array}{l}\text { Human resource diversity management in selected Czech } \\
\text { agricultural companies }\end{array}$ & $\begin{array}{l}\text { Agris On-line Papers in } \\
\text { Economics and } \\
\text { Informatics }\end{array}$ \\
\hline 4 & 2015 & $\begin{array}{l}\text { Cui, Jo, Na \& } \\
\text { Velasquez }\end{array}$ & Workforce Diversity and Religiosity & $\begin{array}{l}\text { Journal of Business } \\
\text { Ethics }\end{array}$ \\
\hline 5 & 2015 & Ledimo & $\begin{array}{l}\text { Diversity management: An organisational culture audit to } \\
\text { determine individual differences }\end{array}$ & $\begin{array}{l}\text { Journal of Applied } \\
\text { Business Research }\end{array}$ \\
\hline 6 & 2016 & Köllen & $\begin{array}{l}\text { Acting Out of Compassion, Egoism, and Malice: A } \\
\text { Schopenhauerian View on the Moral Worth of CSR and } \\
\text { Diversity Management Practices }\end{array}$ & $\begin{array}{l}\text { Journal of Business } \\
\text { Ethics }\end{array}$ \\
\hline 7 & 2017 & $\begin{array}{l}\text { George, Yusuff \& } \\
\text { Cornelius }\end{array}$ & $\begin{array}{l}\text { The good, the bad, and the ugly in the melting pot: The } \\
\text { challenges of Nigerianising diversity management }\end{array}$ & $\begin{array}{l}\text { Equality, Diversity and } \\
\text { Inclusion }\end{array}$ \\
\hline 8 & 2017 & Kim \& Park & $\begin{array}{l}\text { Diversity Management and Fairness in Public } \\
\text { Organizations }\end{array}$ & $\begin{array}{l}\text { Public Organization } \\
\text { Review }\end{array}$ \\
\hline
\end{tabular}




\begin{tabular}{|c|c|c|c|c|}
\hline 9 & 2018 & Raineri & $\begin{array}{l}\text { Diversity management in three Latin American countries: } \\
\text { an institutional theory perspective }\end{array}$ & $\begin{array}{l}\text { Academia Revista } \\
\text { Latinoamericana de } \\
\text { Administracion }\end{array}$ \\
\hline 10 & 2018 & Otaye-Ebede & $\begin{array}{l}\text { Employees' perception of diversity management practices: } \\
\text { scale development and validation }\end{array}$ & $\begin{array}{l}\text { European Journal of } \\
\text { Work and Organizational } \\
\text { Psychology }\end{array}$ \\
\hline 11 & 2018 & $\begin{array}{l}\text { Shore, Cleveland \& } \\
\text { Sanchez }\end{array}$ & Inclusive workplaces: A review and model & $\begin{array}{l}\text { Human Resource } \\
\text { Management Review }\end{array}$ \\
\hline 12 & 2019 & $\begin{array}{l}\text { Ohunakin, Adeniji, } \\
\text { Ogunnaike, Igbadume } \\
\text { \& Akintayo }\end{array}$ & $\begin{array}{l}\text { The effects of diversity management and inclusion on } \\
\text { organisational outcomes: A case of multinational } \\
\text { corporation }\end{array}$ & $\begin{array}{l}\text { Business: Theory and } \\
\text { Practice }\end{array}$ \\
\hline 13 & 2020 & Lee \& Kim & $\begin{array}{l}\text { Workforce diversity and firm performance: Relational } \\
\text { coordination as a mediator and structural empowerment } \\
\text { and multisource feedback as moderators }\end{array}$ & $\begin{array}{l}\text { Human Resource } \\
\text { Management }\end{array}$ \\
\hline 14 & $2020 \mathrm{a}$ & Yadav \& Lenka & Diversity management: a systematic review & $\begin{array}{l}\text { Equality, Diversity and } \\
\text { Inclusion }\end{array}$ \\
\hline 15 & 2020 & $\begin{array}{l}\text { Karolidis, Vouzas, } \\
\text { Kafetsios \& Bellou }\end{array}$ & $\begin{array}{l}\text { Protean Diversity: A Complex Adaptive Systems } \\
\text { Perspective on Individuals within Organizations }\end{array}$ & $\begin{array}{l}\text { European Management } \\
\text { Review }\end{array}$ \\
\hline 16 & 2020 & $\begin{array}{l}\text { Rabl, del Carmen } \\
\text { Triana, Byun \& Bosch }\end{array}$ & $\begin{array}{l}\text { Diversity Management Efforts as an Ethical Responsibility: } \\
\text { How Employees' Perceptions of an Organizational } \\
\text { Integration and Learning Approach to Diversity Affect } \\
\text { Employee Behavior }\end{array}$ & $\begin{array}{l}\text { Journal of Business } \\
\text { Ethics }\end{array}$ \\
\hline 17 & $2020 \mathrm{~b}$ & Yadav \& Lenka & $\begin{array}{l}\text { Workforce diversity: from a literature review to future } \\
\text { research agenda }\end{array}$ & $\begin{array}{l}\text { Journal of Indian } \\
\text { Business Research }\end{array}$ \\
\hline 18 & 2020 & Sinicropi \& Cortese & $\begin{array}{l}\text { (Re)Thinking diversity within sustainable development: A } \\
\text { systematic mapping study }\end{array}$ & $\begin{array}{l}\text { Corporate Social } \\
\text { Responsibility and } \\
\text { Environmental } \\
\text { Management }\end{array}$ \\
\hline 19 & 2020 & $\begin{array}{l}\text { Li, Wang, Haque, } \\
\text { Shafique \& Nawaz }\end{array}$ & $\begin{array}{l}\text { Impact of Workforce Diversity Management on Employees' } \\
\text { Outcomes: Testing the Mediating Role of a person's Job } \\
\text { Match }\end{array}$ & $\begin{array}{l}\text { SAGE Open } \\
10(1)\end{array}$ \\
\hline
\end{tabular}

19 scientific papers published between 2015 and 2020 were identified as a research sample, and the language of the articles is English. After conducted content analysis of the chosen publications included in the research, the sample reveals that only two articles analyse the topic directly and include the literature review on WDM, which is specifically stated in the papers' titles. From the sample we can see two articles written by same authors from India (Yadav \& Lenka, 2020a,b). Additionally, there is one study (Shore, Cleveland \& Sanchez, 2018), which can also be considered as direct analysis with paraphrased keywords. The majority of papers refers to these concepts less directly and are included in the analysis of the definition of WDM. Table 2 confirms that the majority of the papers were published in high-ranking journals; three of the studies were published in Journal of Business Ethics (the Netherlands), two in Equality, Diversity and Inclusion (UK).

The analysis of the full text of the sampled papers enables us to identify key research definitions, analyse the terms of DM and, in particular, emphasize the new formulated definition in the existing literature. Table 3 shows the classified key research definitions, along with a summary of their contribution to the research field. 
Table 3 The key definitions of the workforce diversity management in research

\begin{tabular}{|c|c|c|c|}
\hline No. & Key research definition & Author(s) & Key contribution to the definition of WDM \\
\hline \multirow[t]{5}{*}{1.} & \multirow[t]{5}{*}{$\begin{array}{l}\text { Diversity management defined as } \\
\text { management of individual employees' } \\
\text { differences to contribute to } \\
\text { organisational performance }\end{array}$} & $\begin{array}{l}\text { Ashikali \& Groeneveld } \\
\text { (2015) }\end{array}$ & $\begin{array}{l}\text { In this study, the concept of DM is explained as effective } \\
\text { management of workforce diversity by transforming organizational } \\
\text { culture and practices, assessing distinctions among staff, and } \\
\text { building a beneficial work atmosphere in which a variety of } \\
\text { employees work towards the achievement of organizational } \\
\text { success. }\end{array}$ \\
\hline & & $\begin{array}{l}\text { Lančarič, Chebeň \& } \\
\text { Savov (2015) }\end{array}$ & $\begin{array}{l}\text { The study defines DM as a theory of acknowledging and } \\
\text { appreciating the diversity at a workforce in regard to achieving } \\
\text { companies' performance. It also explains DM as HRM practice, } \\
\text { which increases or maintains variation in the workforce, to ensure } \\
\text { that variation in human capital facilitates the achievement of } \\
\text { organisational goals. }\end{array}$ \\
\hline & & Köllen (2016) & $\begin{array}{l}\text { The author characterises DM as a questionable theory with various } \\
\text { explanations that describe a diverse workforce, targeting to reach } \\
\text { organisational goals in varying approaches. }\end{array}$ \\
\hline & & Otaye-Ebede (2018) & $\begin{array}{l}\text { DM is a concept of utilising strategies to magnify the performance } \\
\text { of organizations; a component of HR policies and practices; and } \\
\text { an inclusive approach which strives to encompass and leverage } \\
\text { variations among employees with the purpose to fully utilize } \\
\text { individual talents and meet organizational goals. }\end{array}$ \\
\hline & & $\begin{array}{l}\text { Ohunakin, Adeniji, } \\
\text { Ogunnaike, Igbadume } \\
\text { \& Akintayo (2019) }\end{array}$ & $\begin{array}{l}\text { DM is the importance of a variety of employees and effectiveness } \\
\text { in the usage of such differences, as well as the application of HRM } \\
\text { initiatives for sustaining a diverse workforce and ensuring absence } \\
\text { of a negative impact on the companies' achievements and } \\
\text { business goals. }\end{array}$ \\
\hline \multirow[t]{2}{*}{2.} & \multirow[t]{2}{*}{$\begin{array}{l}\text { Diversity management as the respect } \\
\text { of individual characteristics regarding } \\
\text { equality and discrimination at } \\
\text { workplaces }\end{array}$} & $\begin{array}{l}\text { Urbancová, } \\
\text { Cermáková \& } \\
\text { Navrátilová (2015) }\end{array}$ & $\begin{array}{l}\text { The description of the DM notion underlines the taking of variation } \\
\text { in the structure of the labour force such as gender, race, family } \\
\text { status, age, sexual orientation, physical and mental abilities as well } \\
\text { as eradicating discrimination from top managers. }\end{array}$ \\
\hline & & $\begin{array}{l}\text { George, Yusuff \& } \\
\text { Cornelius (2017) }\end{array}$ & $\begin{array}{l}\text { The authors describe DM as a "faithful initiative aimed at achieving } \\
\text { equal, diverse and equitable representation without compromising } \\
\text { merit". }\end{array}$ \\
\hline \multirow[t]{4}{*}{3.} & \multirow[t]{4}{*}{$\begin{array}{l}\text { Diversity management considers } \\
\text { individual differences to create } \\
\text { auspicious working conditions and } \\
\text { contribute to organisational } \\
\text { performance }\end{array}$} & Kim \& Park (2017) & $\begin{array}{l}\text { DM is represented as an important managerial tool against } \\
\text { discrimination at the workplace, implemented towards equal } \\
\text { employment opportunities and treatment of workers. DM enhances } \\
\text { social improvement and management practices in a company, } \\
\text { increasing an organization's trust and achieving strong personal } \\
\text { and organizational performance. }\end{array}$ \\
\hline & & $\begin{array}{l}\text { Sinicropi \& Cortese } \\
(2020)\end{array}$ & $\begin{array}{l}\text { The scholars define DM as a method designed to generate and } \\
\text { sustain a favourable atmosphere at a workplace in which all the } \\
\text { similarities and dissimilarities of employees are respected and lead } \\
\text { to ensure sustainable growth by enhancing workforce potential and } \\
\text { maximizing their contribution to the achievement of an } \\
\text { organization's strategic goals. }\end{array}$ \\
\hline & & $\begin{array}{l}\text { Yadav \& Lenka } \\
(2020 a)\end{array}$ & $\begin{array}{l}\text { DM is characterised as a business strategy adopted by } \\
\text { organizations to recognise unique knowledge, recruit and create } \\
\text { an inclusive workplace for individuals from a variety of } \\
\text { backgrounds with a purpose to enhance organizational } \\
\text { effectiveness and corporate performance. }\end{array}$ \\
\hline & & $\begin{array}{l}\text { Rabl, del Carmen } \\
\text { Triana, Byun \& Bosch } \\
(2020)\end{array}$ & $\begin{array}{l}\text { The paper refers to the term called "melting pot" developed in the } \\
\text { USA around } 1780 \text { and expresses incorporating ethnicity, } \\
\text { nationalities, and cultures. The authors argue that DM embodies } \\
\text { inclusion and displays a proactive business approach that } \\
\text { appreciates diversity and builds a beneficial atmosphere, } \\
\text { encouraging achieving business aims such as organizational } \\
\text { learning and organizational success. }\end{array}$ \\
\hline
\end{tabular}




\begin{tabular}{|c|c|c|c|}
\hline & & $\begin{array}{l}\text { Shore, Cleveland \& } \\
\text { Sanchez (2018) }\end{array}$ & $\begin{array}{l}\text { DM refers to the distinct categories of the workforce that have } \\
\text { common cultural or national traits, can fully express themselves } \\
\text { while contributing to the organisational goals, but are influenced by } \\
\text { employment consequences such as employment opportunities, } \\
\text { workplace culture and environment, promotion possibilities } \\
\text { notwithstanding professional experience and qualifications. }\end{array}$ \\
\hline \multirow[t]{7}{*}{4.} & $\begin{array}{l}\text { Diversity management as individual } \\
\text { differences among employees }\end{array}$ & $\begin{array}{l}\text { Cui, Jo, Na \& } \\
\text { Velasquez (2015) }\end{array}$ & $\begin{array}{l}\text { DM is explained by the definition of Harrison and Klein (2007), who } \\
\text { provide a general explanation of diversity as "the distribution of } \\
\text { differences among the members of a unit with concerning a } \\
\text { common attribute, such as tenure, ethnicity, conscientiousness, } \\
\text { task attitude, or pay." }\end{array}$ \\
\hline & & Ledimo (2015) & $\begin{array}{l}\text { The definition of DM states that a group of employees is diverse if } \\
\text { it consists of people with diverse features on which they base their } \\
\text { individuality. }\end{array}$ \\
\hline & & Lee \& Kim (2020) & $\begin{array}{l}\text { DM is defined as a combination of individual characteristics among } \\
\text { the workforce in an organization. }\end{array}$ \\
\hline & & $\begin{array}{l}\text { Karolidis, Vouzas, } \\
\text { Kafetsios \& Bellou } \\
(2020)\end{array}$ & $\begin{array}{l}\text { From the authors' perspective, the workforce can differ regarding } \\
\text { visible and subjective characteristics in respect of employees' } \\
\text { gender, race, age, physical disadvantages, work experience within } \\
\text { an organisation, educational level or background, communicative } \\
\text { skills, cultural values, belief, marital status, sexual orientation, } \\
\text { lifestyle and plenty of other features. }\end{array}$ \\
\hline & & $\begin{array}{l}\text { Yadav \& Lenka } \\
(2020 \mathrm{~b})\end{array}$ & $\begin{array}{l}\text { DM is explained as the composition of work units and an important } \\
\text { collective research phenomenon of different aspects of diversity in } \\
\text { terms of cultural or demographic characteristics, informational } \\
\text { diversity, organizational diversity and cognitive diversity. } \\
\text { Furthermore, it cites Jehn et al. (1999), who explored three specific } \\
\text { types of workgroup diversity: social category diversity; } \\
\text { informational diversity; and value diversity. }\end{array}$ \\
\hline & & Raineri (2018) & $\begin{array}{l}\text { DM relates to the management of employees' variety at work, } \\
\text { including social inequalities and physical differences, such as } \\
\text { appearance and inherent variations, race and gender. }\end{array}$ \\
\hline & & $\begin{array}{l}\text { Li, Wang, Haque, } \\
\text { Shafique \& Nawaz } \\
(2020)\end{array}$ & $\begin{array}{l}\text { DM is defined as management of all individual differences such as } \\
\text { race, gender, age, cultural differences, education, background, } \\
\text { interest, status and physical abilities. }\end{array}$ \\
\hline
\end{tabular}

The following four key research definitions of DM were identified: 1. DM defined as management of individual employees' differences to contribute to organisational performance, 2 . $\mathrm{DM}$ as the respect of individual characteristics regarding equality and discrimination at workplaces, 3. DM as consideration of individual differences to create auspicious working conditions and contribute to organisational performance, 4. DM as individual differences among employees. All the papers explain DM as the management of individual differences among employees; one refers to organisational performance, next cluster explains DM as equality and discrimination at the workplace, the third is the most profitable and combines those two aspects - organisational climate and performance, and the fourth cluster simply explains DM as differences in the workforce. It is worth adding that almost every of the examined articles assumed that there was no evidence of the benefits of DM in organizations.

\section{Discussion and conclusions}

In the past decade, the necessity of WDM in this dynamic and ever-increasing technological age is broadly admitted among researchers, the increasing trend in the number of authors attempting to explain that DM concept can be appreciated. The studied literature allows us to summarize that the main idea of the concept of $\mathrm{DM}$ in existing research is the recognition that the workforce of an organization is comprised of diverse individuals with differences, which can be visible (race, ethnicity, age, gender, physical abilities, etc.) and invisible (education, competencies and skills, motivation, work experience, etc.) (Ledimo, 2015; Sinicropi \& 
Cortese, 2020; Yadav \& Lenka, 2020b). Most of the authors acknowledge DM as a tool that has to be considered if an organization wants individuals to contribute to organizational performance. Hardly a fourth of the papers converge on apprehending the potential value of individual differences regarding the creation of a positive environment in which employees are appreciated and their abilities are fully acknowledged.

In an early study on DM (Ghosh, 2016), it was predicted that companies should be careful in managing human capital as the business environment is experiencing an extensive transformation. The study (Sung \& Choi, 2019) argues that many organisations were led to rethink and re-design their organisational cultures due to changing demographic dynamics of the labour force. Moreover, in the current circumstances of the COVID-19 restrictions, organizations are put in a quandary and have to revise, invent and implement new policies and practices with a purpose to hire, retain and to rally distributed teams with different backgrounds, which carries both certain difficulties and advantages. Organisations that follow global trends should instantly adjust to the changes (Urbancová et al., 2015). Thus, the new challenge for managers arises in the obstacles, that in current crises, DM has to be implemented and adjust remotely and in a short time, and to show more productive results than ever. As the first step to the implementation of this approach into organisational management, it is crucial for managers to clearly understand the definition of WDM. Therefore, this article contributes to theoretical research by evaluating the DM definition and the materials will be interesting and useful to Human Resources professionals in various sectors of the economy, aimed at longterm business development.

The study has some limitations in the research process. At first, the chosen database (Scopus) does not contain all the contemporary studies on the research topic. The second consists of the limits in the systematic literature review used for the research methodology. Considering these reasons, further in-depth studies within the field can be conducted. Moreover, new research directions could be developed. In particular, it would be interesting to investigate WDM practice and case studies in virtual teams; trends and innovative approaches (digital HR) in DM; and dimensions of diversity that are relevant to the workplace.
In conclusion, it might be stated that the purpose of this article was achieved by analyzing the literature on the theory of managing a diverse workforce in organizations. The results show that the concept of WDM concerning creating a supportive work environment and, at the same time, achieving organizational goals is not very popular in existing research. The application of systematic literature review as a methodology gives the right to conclude that research gaps were identified.sm

\section{References}

Ayega, E. N. \& Muathe, S. (2018). Critical Review of Literature on Cultural Diversity in the Work Place and Organizational Performance: A Research Agenda. Journal of Human Resource Management, 6(1), 9-17. https://doi.org/10.11648/j.jhrm.20180601.12

Ashikali, T., \& Groeneveld, S. (2015). Diversity management for all? an empirical analysis of diversity management outcomes across groups. Personnel Review, 44(5), 757-780.

https://doi.org/10.1108/PR-10-2014-0216

Bridgstock, R., Lettice, F., Ozbilgin, M.F., \& Tatli, A. (2010). Diversity Management for Innovation in Social Enterprises in the UK. Entrepreneurship and Regional Development, 22(6), 557-574.

https://doi.org/10.1080/08985626.2010.488404

Choi, S. \& Rainey, H.G. (2010). Managing Diversity in U.S. Federal Agencies: Effects of Diversity and Diversity Management on Employee Perceptions of Organizational Performance. Public Administration Review, 70. 109-121. https://doi.org/10.1111/j.1540-6210.2009.02115.x

Cui, J., Jo, H., Na, H., \& Velasquez, M. G. (2015). Workforce diversity and religiosity. Journal of Business Ethics, 128(4), 743-767. https://doi.org/10.1007/s10551-013-1984-8

Egerova, D. (2012). Diversity management as a crucial issue of the management in the 21 st century. Problems of Management in the 21st Century, 2(3), 5-7.

Egerova, D., Jiřincová, M., Lančarič, D., \& Savov, R. (2013). Applying the concept of diversity management in organisations in the Czech republic and the Slovak republic - a research survey. Technological and Economic Development of Economy, 19(2), 350-366. https://doi.org/10.3846/20294913.2013.798598

Fischer, M. (2009). Diversity management and the business case. In Kraal K., Roosblad J., \& Wrench J. (Eds.), Equal Opportunities and Ethnic Inequality in European Labour Markets: Discrimination, Gender and Policies of Diversity, 95-118. Amsterdam: Amsterdam University Press. https://doi.org/10.5117/9789089641267

George, O., Yusuff, K.M., \& Cornelius, N. (2017). The good, the bad, and the ugly in the melting pot: The challenges of Nigerianising diversity management, Equality, Diversity and Inclusion, 36(3), 238-254. https://doi.org/10.1108/EDI-10-2015-0088 
Ghosh, K. (2016). Creative leadership for workplace innovation: An applied SAP-LAP framework. Development and Learning in Organizations: $A n$ International Journal, 30, 10-14. https://doi.org/10.1108/DLO-04-2015-0041

Gröschl, S. (2011). Diversity management strategies of global hotel groups: A corporate web site based exploration. International Journal of Contemporary Hospitality Management, 23(2), 224-240. https://doi.org/10.1108/09596111111119347

Hubbard, E. E. (2011). The diversity scorecard: evaluating the impact of diversity on organizational performance (improving human performance). Burlington: Butterworth-Heinemann.

Inegbedion, H., Sunday, E., Asaleye, A., Lawal, A., \& Adebanji, A. (2020). Managing Diversity for Organizational Efficiency. SAGE Open.10(1). https://doi.org/10.1177/2158244019900173

Karolidis, D., Vouzas, F., Kafetsios, K., \& Bellou, V. (2020). Protean diversity: A complex adaptive systems perspective on individuals within organizations. European Management Review. 177(4), 857-870 https://doi.org/10.1111/emre.12399

Kim, S., Park, S. (2017). Diversity Management and Fairness in Public Organizations. Public Organiz Rev 17(2), 179-193. https://doi.org/10.1007/s11115-015-0334-y

Köllen, T. (2016). Acting out of compassion, egoism, and malice: A schopenhauerian view on the moral worth of CSR and diversity management practices. Journal of Business Ethics, 138(2), 215-229. https://doi.org/10.1007/s10551-015-2599-z

Lančarič, D., Chebeň, J., \& Savov, R. (2015). Factors influencing the implementation of diversity management in business organisations in a transition economy. The case of Slovakia. Economic Research-Ekonomska Istrazivanja, 28(1), 1162-1184. https://doi.org/10.1080/1331677X.2015.1100837

Ledimo, O. (2015). Diversity management: An organisational culture audit to determine individual differences. Journal of Applied Business Research, 31 (5), 1747-1756. https://doi.org/10.19030/jabr.v31i5.9388

Lee, H. W., \& Kim, E. (2020). Workforce diversity and firm performance: Relational coordination as a mediator and structural empowerment and multisource feedback as moderators. Human Resource Management, 59(1), 523. https://doi.org/10.1002/hrm.21970

Li, W., Wang, X., Haque, M. J., Shafique, M. N., \& Nawaz, M. Z. (2020). Impact of workforce diversity management on employees' outcomes: Testing the mediating role of a person's job match. SAGE Open, 10(1). https://doi.org/10.1177/2158244020903402

Manoharan, A., \& Singal, M. (2017). A systematic literature review of research on diversity and diversity management in the hospitality literature. International Journal of Hospitality Management, 66, 77-91. https://doi.org/10.1016/j.ijhm.2017.07.002

Mcdonald, D. (2010). The Evolution of 'Diversity Management' in the USA: Social Contexts, Managerial Motives and Theoretical Approaches. Institute of Business Research, Daito Bunka University. Research Papers, 1-20.
Meena, K., \& Vanka, S. (2017). Developing an empirical typology of diversity-oriented human resource management practices. Journal of Management Development, 36(7), 915-929. https://doi.org/10.1108/JMD-02-2016-0031

Mengist W., Soromessa T., \& Legese G. (2020). Method for conducting systematic literature review and metaanalysis for environmental science research. MethodsX, 7. https://doi.org/10.1016/j.mex.2019.100777

Ohunakin, F., Adeniji, A., Ogunnaike, O. O., Igbadume, F., \& Akintayo, D. I. (2019). The effects of diversity management and inclusion on organisational outcomes: a case of multinational corporation. Business: Theory and Practice, 20, 93-102.

https://doi.org/10.3846/btp.2019.09

Otaye-Ebede L. (2018). Employees' perception of diversity management practices: scale development and validation. European Journal of Work and Organizational Psychology, 27(4), 462-476. https://doi.org/10.1080/1359432X.2018.1477130

Ozbilgin M.F., Jonsen K., Tatli A., Vassilopoulou J., \& Surgevil O. (2013). Global diversity management. In Roberson QM, editors. The Oxford Handbook of Diversity and Work. Oxford University Press: Oxford, 419-441. https://doi.org/10.1093/oxfordhb/9780199736355.013.0 $\underline{022}$

Pitts, D. (2009). Diversity Management, Job Satisfaction, and Performance: Evidence from U.S. Federal Agencies. Public Administration Review, 69(2), 328338.

https://doi.org/10.1111/j.1540-6210.2008.01977.x

Rabl, T., del Carmen Triana, M., Byun, S.Y., \& Bosch L. (2020). Diversity Management Efforts as an Ethical Responsibility: How Employees' Perceptions of an Organizational Integration and Learning Approach to Diversity Affect Employee Behavior. Journal of Business Ethics, 161(3), 531-550. https://doi.org/10.1007/s10551-018-3849-7

Raineri, A. (2018). Diversity management in three Latin American countries: an institutional theory perspective. Academia Revista Latinoamericana de Administración, 31(2), 426-447. https://doi.org/10.1108/ARLA-08-2016-0220

Ramsiary S., \& Raya P. (2015). Diversity Management - A Blend of Literature, Pacific Business Review International, $7(10)$.

Roosevelt Thomas, R. (1990). From affirmative action to affirming diversity. Harvard Business Review, 68(2), 107-117.

Sanghvi, P. (2019). Diversity and strategic Human Resources management: literature review. PEOPLE: International Journal of Social Sciences, 5(2), 153-161. https://doi.org/10.20319/pijss.2019.52.153161

Saxena A. (2014). Workforce Diversity: A Key to Improve Productivity, Procedia Economics and Finance, 11, 7685. https://doi.org/10.1016/S2212-5671(14)00178-6

Scopus. (2020). Scopus. Retrieved December 2020 from: https://www.scopus.com/ 
Shen, J., Tang, N., \& D'Netto, B. (2014). A multilevel analysis of the effects of HR diversity management on employee knowledge sharing: The case of Chinese employees. The International Journal of Human Resource Management, 25(12), 1720-1738. https://doi.org/10.1080/09585192.2013.859163

Shore, L. M., Cleveland, J. N., \& Sanchez, D. (2018). Inclusive workplaces: A review and model. Human Resource Management Review, 28 (2), 176-189. https://doi.org/10.1016/j.hrmr.2017.07.003

Sinicropi, S., \& Cortese, D. (2020). (Re)Thinking diversity within sustainable development: A systematic mapping study. Corporate Social Responsibility and Environmental Management, 28(1), 299-309. https://doi.org/10.1002/csr.2050

Snyder, H. (2019). Literature review as a research methodology: An overview and guidelines. Journal of Business Research, 104, 333-339. https://doi.org/10.1016/j.jbusres.2019.07.039

Sung, S.Y. and Choi, J.N. (2019). Contingent effects of workforce diversity on firm innovation: high-tech industry and market turbulence as critical environmental contingencies. The International Journal of Human Resource Management, 1-27.

\section{$\bowtie$ Correspondence}

\section{Seliverstova Yana}

\section{PhD Student}

University of Debrecen, Hungary

Faculty of Economics and Business

4032 Böszörményi út 138, Debrecen, Hungary

E-mail: seliverstova.ys@gmail.com https://doi.org/10.1080/09585192.2019.1579243

Tamunomiebi, M. D., \& John-Eke, E. C. (2020). Workplace Diversity: Emerging Issues in Contemporary Reviews. International Journal of Academic Research in Business and Social Sciences, 10(2), 255-265. https://doi.org/10.6007/IJARBSS/v10-i2/6926

Urbancová, H., Cermáková, H., \& Navrátilová, M. (2015). Human resource diversity management in selected czech agricultural companies. Agris on-Line Papers in Economics and Informatics, 7(3), 79-87. https://doi.org/10.7160/aol.2015.070308

Urbancová, H.; Hudáková, M.; Fajčíková, A. (2020). Diversity Management as a Tool of Sustainability of Competitive Advantage. Sustainability, 12(12), 5020. https://doi.org/10.3390/su12125020

Yadav, S., \& Lenka, U. (2020a). Diversity management: A systematic review. Equality, Diversity and Inclusion, 39 (8), 901-929. https://doi.org/10.1108/EDI-07-2019-0197

Yadav, S., \& Lenka, U. (2020b). Workforce diversity: from a literature review to future research agenda. Journal of Indian Business Research, 12(4), 577-603. https://doi.org/10.1108/JIBR-08-2019-0243 